\title{
Synthesis of the C6-C21 Segment of Amphidinolide E
}

\author{
James A. Marshall, Gregory Schaaf, and Andrew Nolting \\ Department of Chemistry, University of Virginia \\ Charlottesville, VA 22904
}

Supporting Information: Experimental procedures for all new compounds 17 pages 


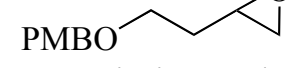

\section{(士)-4-(p-Methoxybenzyloxy)-1,2-epoxybutane}

To a stirring solution of $p$-methoxybenzyl 3-butenyl ether (33.7 g, $0.18 \mathrm{~mol}$ ) in $\mathrm{CH}_{2} \mathrm{Cl}_{2}$ (1.2 L) was added MCPBA $(77 \%, 50.0 \mathrm{~g}, 0.22 \mathrm{mmol})$ After stirring overnight, the reaction mixture was quenched by addition of saturated aqueous $\mathrm{Na}_{2} \mathrm{~S}_{2} \mathrm{O}_{3}$. A $10 \%$ aqueous solution of $\mathrm{NaOH}$ was added dropwise to dissolve the resultant solids and the layers were separated. The aqueous phase was extracted with $\mathrm{CH}_{2} \mathrm{Cl}_{2}$ and the combined organic layers were dried over $\mathrm{MgSO}_{4}$, filtered, and concentrated under reduced pressure. The residue was purified by bulb-to-bulb distillation $\left(0.05 \mathrm{~mm} / \mathrm{Hg}, 160^{\circ} \mathrm{C}\right)$ to give $31.7 \mathrm{~g}$ (87\%) of epoxide as a clear liquid. ${ }^{1} \mathrm{H}$ NMR $\left(300 \mathrm{MHz}, \mathrm{CDCl}_{3}\right) \_7.32(\mathrm{~d}, J=1.77 \mathrm{~Hz}$, 2H), $6.93(\mathrm{~d}, J=1.70 \mathrm{~Hz}, 2 \mathrm{H}), 4.56(\mathrm{~s}, 2 \mathrm{H}), 3.79(\mathrm{~s}, 3 \mathrm{H}), 3.53(\mathrm{t}, J=5.7 \mathrm{~Hz}, 2 \mathrm{H}), 3.01$ (m, 1H), $2.78(\mathrm{~m}, 1 \mathrm{H}), 2.52(\mathrm{~m}, 1 \mathrm{H}), 2.02(\mathrm{~m}, 2 \mathrm{H})$.

\section{${ }_{\mathrm{PMBO}}^{\mathrm{O}} \sim \mathrm{Y}_{\text {Epoxide } 1}$}

To a flame-dried round-bottomed flask equipped with a stirbar was added the $(R, R)$ (salen)Co(II) precatalyst (491 mg, $0.813 \mathrm{mmol}$ ) followed sequentially by freshly distilled ( \pm )-PMB epoxy ether $(33.87 \mathrm{~g}, 163 \mathrm{mmol})$ and $\mathrm{AcOH}(186 \mu \mathrm{L}, 3.25 \mathrm{mmol})$. After the reaction mixture turned from a red suspension to a dark brown solution $(0.25 \mathrm{~h})$, the solution was cooled to $0{ }^{\circ} \mathrm{C}$ and THF $(2 \mathrm{~mL})$ and water $(1.30 \mathrm{~mL}, 81.3 \mathrm{mmol})$ were added. The reaction mixture was allowed to warm to room temperature over $2 \mathrm{~h}$ and stirred overnight. The $(S)$-PMB epoxy ether was removed by careful bulb-to-bulb distillation $\left(0.05 \mathrm{~mm} / \mathrm{Hg}, 160{ }^{\circ} \mathrm{C}\right)$ from the reaction mixture to yield $15.9 \mathrm{~g}(47 \%)$ of epoxide 1 as a clear oil. $[\alpha]^{20}{ }_{\mathrm{D}}-12.3\left(c 1.00, \mathrm{CHCl}_{3}\right){ }^{1} \mathrm{H} \mathrm{NMR}\left(300 \mathrm{MHz}, \mathrm{CDCl}_{3}\right) \_7.32$ 
(d, $J=1.77 \mathrm{~Hz}, 2 \mathrm{H}), 6.93(\mathrm{~d}, J=1.70 \mathrm{~Hz}, 2 \mathrm{H}), 4.50(\mathrm{~s}, 2 \mathrm{H}), 3.78(\mathrm{~s}, 3 \mathrm{H}), 3.52(\mathrm{t}, J=5.7$

$\mathrm{Hz}, 2 \mathrm{H}), 3.06(\mathrm{~m}, 1 \mathrm{H}), 2.78(\mathrm{~m}, 1 \mathrm{H}), 2.52(\mathrm{~m}, 1 \mathrm{H}), 2.02(\mathrm{~m}, 2 \mathrm{H})$.

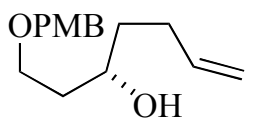

\section{Alcohol 2}

To a suspension of freshly purified CuI (1.34 g, $7.04 \mathrm{mmol})$ in THF (315 $\mathrm{mL})$ at $-30{ }^{\circ} \mathrm{C}$ was added allylmagnesium chloride $\left(2 \mathrm{M}\right.$ in $\left.\mathrm{Et}_{2} \mathrm{O}, 35.2 \mathrm{~mL}\right)$ over $0.25 \mathrm{~h}$. The reaction mixture was stirred an additional $5 \mathrm{~min}$ followed by the addition of a solution of epoxide 1 (10.5 g, $50.4 \mathrm{mmol})$ in THF $(53 \mathrm{~mL})$ over $0.25 \mathrm{~h}$. The reaction mixture was allowed to warm to $0{ }^{\circ} \mathrm{C}$ and stirred for an additional $0.5 \mathrm{~h}$. The reaction mixture was quenched with aqueous $\mathrm{NH}_{4} \mathrm{Cl} / \mathrm{NaOH}(9: 1)$ and $\mathrm{Et}_{2} \mathrm{O}$ and transferred to a separatory funnel. The aqueous layer was separated and extracted with $\mathrm{Et}_{2} \mathrm{O}$. The combined organic extracts were washed with brine, dried over $\mathrm{MgSO}_{4}$, and filtered. The solution was concentrated to give $12.6 \mathrm{~g}$ (100\%, crude) of alcohol 2 which was used in the next step with no further purification. $[\alpha]^{20}-8.3\left(c 1.00, \mathrm{CHCl}_{3}\right):{ }^{1} \mathrm{H}_{\mathrm{NMR}}(300$ $\left.\mathrm{MHz}_{\mathrm{CDCl}}\right)_{-} 7.24(\mathrm{~d}, J=8.5 \mathrm{~Hz}, 2 \mathrm{H}), 6.87(\mathrm{~d}, J=8.5 \mathrm{~Hz}, 2 \mathrm{H}), 5.84(\mathrm{~m}, 1 \mathrm{H}), 5.07-$ $4.96(\mathrm{~m}, 2 \mathrm{H}), 4.45(\mathrm{~s}, 2 \mathrm{H}), 3.83(\mathrm{~m}, 1 \mathrm{H}), 3.81(\mathrm{~s}, 3 \mathrm{H}), 3.70(\mathrm{~m}, 1 \mathrm{H}), 3.63(\mathrm{~m}, 1 \mathrm{H}), 2.20$ $(\mathrm{m}, 1 \mathrm{H}), 2.12(\mathrm{~m}, 1 \mathrm{H}), 1.74(\mathrm{~m}, 2 \mathrm{H}), 1.58(\mathrm{~m}, 1 \mathrm{H}), 1.52(\mathrm{~m}, 1 \mathrm{H})$.

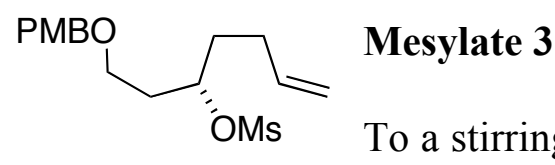

$(10 \mathrm{~mL})$ at $0{ }^{\circ} \mathrm{C}$ was sequentially added triethylamine $(0.278 \mathrm{~mL}, 2.00 \mathrm{mmol})$ and $\mathrm{MsCl}$ $(0.116 \mathrm{~mL}, 1.500 \mathrm{mmol})$. After stirring for $0.5 \mathrm{~h}$, the reaction mixture was quenched with water, the layers were separated, and the aqueous layer was extracted with $\mathrm{CH}_{2} \mathrm{Cl}_{2}$. The 
combined organic extracts were dried over $\mathrm{MgSO}_{4}$, filtered, and concentrated under reduced pressure to give $0.312 \mathrm{~g}$ ( $95 \%$ over two steps) of mesylate $\mathbf{3}$ as a light yellow oil which was used without further purification. $[\alpha]^{20}{ }_{\mathrm{D}}+9.3\left(c\right.$ 1.00, $\left.\mathrm{CHCl}_{3}\right):{ }^{1} \mathrm{H} \mathrm{NMR}$ $\left(\mathrm{CDCl}_{3}, 300 \mathrm{MHz}\right) ; \delta 7.26(\mathrm{~d}, J=9.0 \mathrm{~Hz}, 2 \mathrm{H}), 6.84(\mathrm{~d}, J=9.0 \mathrm{~Hz}, 2 \mathrm{H}), 5.79$ (ddd, $J=$ 1.5, 1.5, $15.0 \mathrm{~Hz}, 1 \mathrm{H}), 5.08(\mathrm{~m}, 2 \mathrm{H}), 5.01(\mathrm{~m}, 1 \mathrm{H}), 4.98(\mathrm{~m}, 1 \mathrm{H}), 4.42$ (q, $J=6.9 \mathrm{~Hz}$, 2H), $3.88(\mathrm{~s}, 3 \mathrm{H}), 3.58(\mathrm{~m}, 2 \mathrm{H}), 2.97(\mathrm{~s}, 3 \mathrm{H}), 2.17(\mathrm{~m}, 2 \mathrm{H}), 1.99(\mathrm{~m}, 2 \mathrm{H}), 1.84(\mathrm{~m}, 2 \mathrm{H})$.

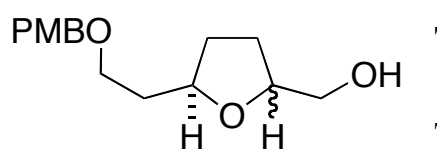

\section{Tetrahydrofuran 4}

To a solution of mesylate $3(123 \mathrm{mg}, 0.304 \mathrm{mmol})$ in $t$ $\mathrm{BuOH} /$ water/acetone $(2: 2: 1,5 \mathrm{~mL})$ was added NMO $(53.5 \mathrm{mg}, 1.02 \mathrm{mmol})$ and $\mathrm{OsO}_{4}$ (2.5 $\mathrm{wt} \%$ in toluene, $0.095 \mu \mathrm{mol})$. After stirring overnight, the reaction mixture was quenched by the addition of solid $\mathrm{Na}_{2} \mathrm{SO}_{3}$ and stirred for an additional $1 \mathrm{~h}$. Diethyl ether was added to the mixture and the layers were separated. The aqueous layer was further extracted with $\mathrm{Et}_{2} \mathrm{O}$ and the combined organic extracts were washed with brine, dried over $\mathrm{MgSO}_{4}$, and filtered. The solution was concentrated under reduced pressure and the residue was chromatographed on silica gel (gradient elution with $50 \%$ to $100 \%$ EtOAc/hexanes) to give (72\%) of hydroxy ether $\mathbf{4}$ as a viscous light yellow oil. $[\alpha]^{20}{ }_{\mathrm{D}}+$ $2.4\left(c 1.00, \mathrm{CHCl}_{3}\right):{ }^{1} \mathrm{H} \mathrm{NMR}\left(\mathrm{CDCl}_{3}, 300 \mathrm{MHz}\right) ; \delta 7.26(\mathrm{~d}, J=9.0 \mathrm{~Hz}, 2 \mathrm{H}), 6.84(\mathrm{~d}, J=$ $9.0 \mathrm{~Hz}, 2 \mathrm{H}), 4.44(\mathrm{~s}, 2 \mathrm{H}), 4.05(\mathrm{~m}, 2 \mathrm{H}), 3.80(\mathrm{~s}, 3 \mathrm{H}), 3.72-3.48(\mathrm{~m}, 4 \mathrm{H}), 2.02-1.58(\mathrm{~m}$, $6 \mathrm{H})$. 


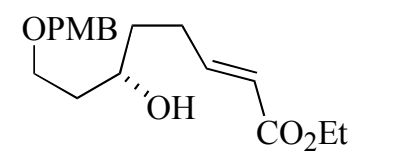

\section{Unsaturated Ester 5}

To a solution of olefin $2(159 \mathrm{mg}, 0.639 \mathrm{mmol})$ in $\mathrm{CH}_{2} \mathrm{Cl}_{2}(6 \mathrm{~mL})$ was added ethyl acrylate $(383 \mathrm{mg}, 3.830 \mathrm{mmol})$ and Hoveyda-Grubbs II catalyst (12 mg, $0.019 \mathrm{mmol})$. After 3-4 $\mathrm{h}$ at reflux the reaction was judged complete by TLC analysis at which point the mixture was concentrated under reduced pressure and subjected directly to column chromatography on silica gel (10:1 to 3:1 hexanes:ether) to give ester 5 (160 mg, 80\%) as a colorless oil: $[\alpha]^{20}{ }_{\mathrm{D}}-14.1\left(c 1.00, \mathrm{CHCl}_{3}\right) ;{ }^{1} \mathrm{H} \mathrm{NMR}\left(300 \mathrm{MHz}, \mathrm{CDCl}_{3}\right)$ $7.24(\mathrm{~d}, J=8.5 \mathrm{~Hz}, 2 \mathrm{H}), 7.06(\mathrm{dt}, J=6.9,1.2,6.9 \mathrm{~Hz}, 1 \mathrm{H}), 6.87(\mathrm{~d}, J=8.5 \mathrm{~Hz}, 2 \mathrm{H}), 5.88$ (d, $12.5 \mathrm{~Hz}, 1 \mathrm{H}), 4.47$ (s, 2H), 4.21 (q, $J=7.1 \mathrm{~Hz}, 2 \mathrm{H}), 3.82(\mathrm{~s}, 3 \mathrm{H}), 3.65(\mathrm{~m}, 2 \mathrm{H}), 3.12$ (d, $J=2.9 \mathrm{~Hz}, 1 \mathrm{H}), 2.37(\mathrm{~m}, 2 \mathrm{H}), 1.64(\mathrm{~m}, 4 \mathrm{H}) 1.31(\mathrm{t}, J=7.1 \mathrm{~Hz}, 3 \mathrm{H})$.

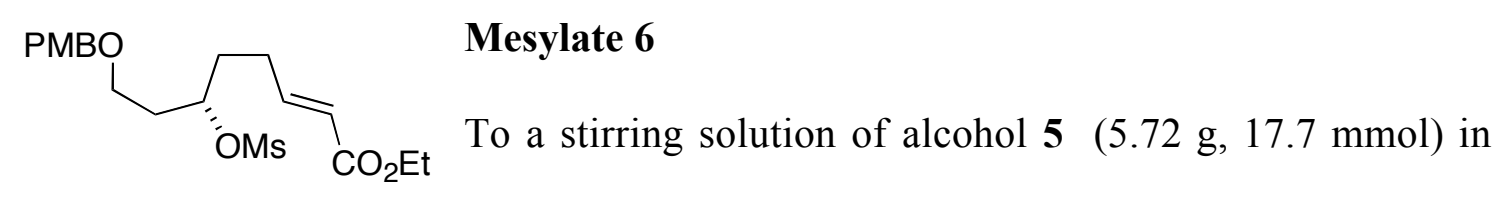

$\mathrm{CH}_{2} \mathrm{Cl}_{2}(175 \mathrm{~mL})$ at $0{ }^{\circ} \mathrm{C}$ was sequentially added triethylamine $(4.94 \mathrm{~mL}, 35.5 \mathrm{mmol})$ and $\mathrm{MsCl}(2.06 \mathrm{~mL}, 26.7 \mathrm{mmol})$. After stirring for $0.5 \mathrm{~h}$, the reaction mixture was quenched with water, the layers were separated, and the aqueous layer was extracted with $\mathrm{CH}_{2} \mathrm{Cl}_{2}$. The combined organic extracts were dried over $\mathrm{MgSO}_{4}$, filtered, and concentrated under reduced pressure to give $7.16 \mathrm{~g}(100 \%)$ of mesylate 6 as a light yellow oil which was used without further purification. $[\alpha]^{20}{ }_{\mathrm{D}}+4.2\left(c 1.00, \mathrm{CHCl}_{3}\right):{ }^{1} \mathrm{H}$ $\operatorname{NMR}\left(\mathrm{CDCl}_{3}, 300 \mathrm{MHz}\right) ; \delta 7.26(\mathrm{~d}, J=9.0 \mathrm{~Hz}, 2 \mathrm{H}), 6.95(\mathrm{~m}, 1 \mathrm{H}), 6.88(\mathrm{~d}, J=9.0 \mathrm{~Hz}$, 2H), $5.86(\mathrm{ddd}, J=1.5,1.5,15.0 \mathrm{~Hz}, 1 \mathrm{H}), 5.60(\mathrm{~m}, 1 \mathrm{H}), 4.42(\mathrm{~d}, J=5.1 \mathrm{~Hz}, 2 \mathrm{H}), 4.19$ (q, $J=6.9 \mathrm{~Hz}, 2 \mathrm{H}), 3.81(\mathrm{~s}, 3 \mathrm{H}), 3.55(\mathrm{~m}, 2 \mathrm{H}), 2.97$ (s, 3H), $2.33(\mathrm{~m}, 2 \mathrm{H}), 1.96(\mathrm{~m}, 2 \mathrm{H})$, $1.88(\mathrm{~m}, 2 \mathrm{H}), 1.28(\mathrm{t}, J=6.9 \mathrm{~Hz}, 3 \mathrm{H})$. 


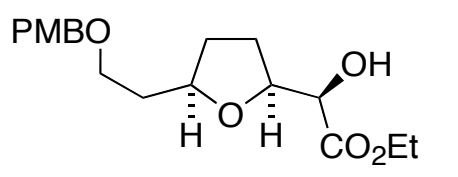

\section{Tetrahydrofuran 7}

To a well stirred suspension of AD-mix- $\alpha$ (4.75 g, 1.4 $\mathrm{g} / \mathrm{mmol})$ in $t-\mathrm{BuOH} / \mathrm{H}_{2} \mathrm{O}(1: 1,30 \mathrm{~mL})$ was added methanesulfonamide (323 $\mathrm{mg}, 3.39$ mmol) with stirring until both phases were nearly clear $(\sim 0.25 \mathrm{~h})$. The reaction mixture was cooled to $0{ }^{\circ} \mathrm{C}$ and mesylate $6(1.36 \mathrm{~g}, 3.39 \mathrm{mmol})$ was added with a $t-\mathrm{BuOH} / \mathrm{H}_{2} \mathrm{O}$ rinse $(4 \mathrm{~mL})$. The mixture was allowed to warm to $\mathrm{rt}$ and stirred for $1 \mathrm{~d}$. The reaction was quenched by the addition of aqueous $\mathrm{Na}_{2} \mathrm{SO}_{3}(5.09 \mathrm{~g})$ and stirred for $1 \mathrm{~h}$. The mixture was extracted with $\mathrm{CH}_{2} \mathrm{Cl}_{2}$ and $\mathrm{Et}_{2} \mathrm{O}$ and the combined organic extracts were dried over $\mathrm{MgSO}_{4}$, filtered, and concentrated under reduced pressure. The residue was chromatographed on silica gel (gradient elution with $20 \%$ to $50 \%$ EtOAc/hexanes) to give $987 \mathrm{mg}(87 \%)$ of tetrahydrofuran 7 as a mostly separable mixture of $850 \mathrm{mg}(75 \%)$ cis and $137 \mathrm{mg}(12 \%)$ of mixed cis and trans fractions as light yellow oils. (Note: there is no difference in the $\mathrm{R}_{\mathrm{f}}$ of the starting material and product.) $[\alpha]^{20}{ }_{\mathrm{D}}+8.0$ (c 1.00, $\left.\mathrm{CHCl}_{3}\right):{ }^{1} \mathrm{H} \mathrm{NMR}\left(\mathrm{CDCl}_{3}, 300 \mathrm{MHz}\right) ; \delta 7.25(\mathrm{~d}, J=9.0 \mathrm{~Hz}, 2 \mathrm{H}), 6.86(\mathrm{~d}, J=8.7 \mathrm{~Hz}, 2 \mathrm{H})$, $4.43(\mathrm{~d}, J=3.3 \mathrm{~Hz}, 2 \mathrm{H}), 4.21(\mathrm{~m}, 3 \mathrm{H}), 4.05(\mathrm{~m}, 2 \mathrm{H}), 3.80(\mathrm{~s}, 3 \mathrm{H}), 3.54(\mathrm{dd}, J=6.6,6.6$ $\mathrm{Hz}, 2 \mathrm{H}), 2.10-1.50(\mathrm{~m}, 6 \mathrm{H}), 1.29(\mathrm{dd}, J=6.9,6.9 \mathrm{~Hz}, 3 \mathrm{H})$.

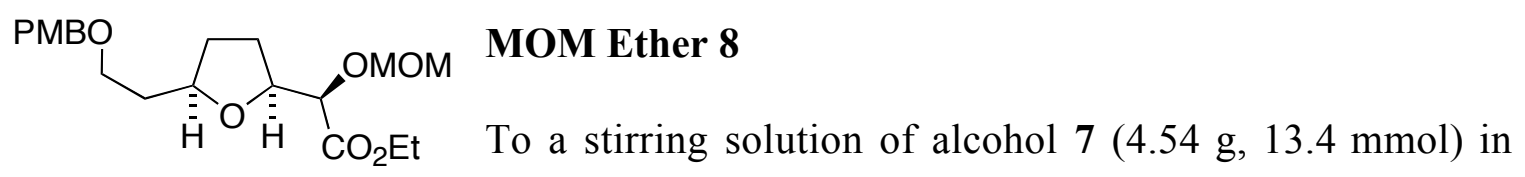
$\mathrm{CH}_{2} \mathrm{Cl}_{2}$ was sequentially added Hunig's base (16.3 mL, $\left.94.0 \mathrm{mmol}\right), \mathrm{MOMCl}(6.06 \mathrm{~mL}$, $80.4 \mathrm{mmol})$, and TBAI (2.27 $\mathrm{g}, 6.15 \mathrm{mmol})$. The reaction vessel was shielded from light by wrapping the round bottomed flask in aluminum foil, and the reaction mixture was 
stirred overnight. The reaction was quenched by the addition of an aqueous solution of $\mathrm{NaHCO}_{3}$ and extracted with $\mathrm{CH}_{2} \mathrm{Cl}_{2}$. The combined organic extracts were dried over $\mathrm{MgSO}_{4}$, filtered, and concentrated under reduced pressure. Column chromatography on silica gel (gradient elution with $25 \%$ to $50 \%$ EtOAc/hexanes) gave $5.20 \mathrm{~g}(100 \%)$ of MOM ether 8 as a light yellow oil. $[\alpha]^{20}{ }_{D}+19.5\left(c 1.00, \mathrm{CHCl}_{3}\right):{ }^{1} \mathrm{H}$ NMR $\left(\mathrm{CDCl}_{3}, 300\right.$ MHz); $\delta 7.25(\mathrm{~d}, J=9.0 \mathrm{~Hz}, 2 \mathrm{H}), 6.86(\mathrm{~d}, J=8.7 \mathrm{~Hz}, 2 \mathrm{H}), 4.72(\mathrm{~s}, 2 \mathrm{H}), 4.42(\mathrm{~d}, J=3.3$ Hz, 2H), $4.21(\mathrm{~m}, 3 \mathrm{H}), 4.06(\mathrm{~m}, 1 \mathrm{H}), 4.02(\mathrm{~m}, 1 \mathrm{H}), 3.80(\mathrm{~s}, 3 \mathrm{H}), 3.54(\mathrm{dd}, J=6.6,6.6$ Hz, 2H), 3.39 (s, 3H), $1.94-1.87$ (m, 5H), 1.57 (m, 1H), 1.31 (dd, $J=6.9,6.9 \mathrm{~Hz}, 3 \mathrm{H})$.

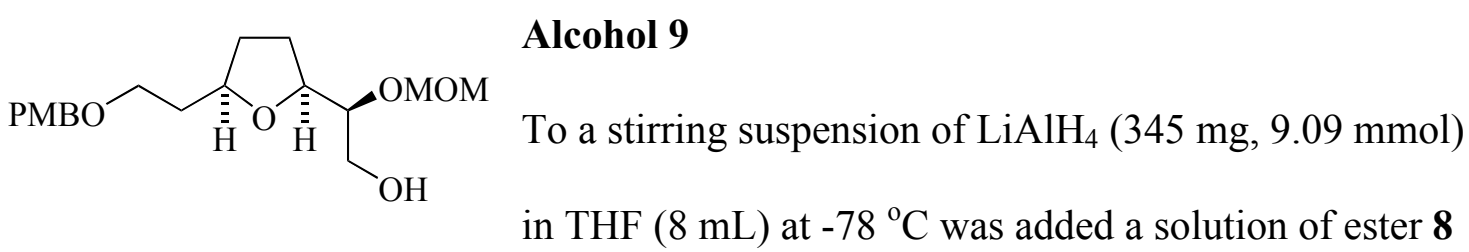

(580 mg, $1.52 \mathrm{mmol})$ in THF $(7 \mathrm{~mL})$ slowly over $0.25 \mathrm{~h}$. The reaction mixture was warmed to $\mathrm{rt}$ and stirred for $1.5 \mathrm{~h}$. The reaction was quenched at $0{ }^{\circ} \mathrm{C}$ by the sequential addition of water $(0.340 \mathrm{~mL}), 10 \% \mathrm{NaOH}(0.510 \mathrm{~mL})$, and water $(1.0 \mathrm{~mL})$ with $0.25 \mathrm{~h}$ of stirring between each addition. The mixture was filtered though a plug of Celite to give $456 \mathrm{mg}(88 \%)$ of alcohol 9 as a clear oil which was used without purification $[\alpha]^{20}-30.1$ (c 1.00, $\left.\mathrm{CHCl}_{3}\right) ;:{ }^{1} \mathrm{H}$ NMR $\left(300 \mathrm{MHz}, \mathrm{CDCl}_{3}\right) \_7.24(\mathrm{~d}, J=8.5 \mathrm{~Hz}, 2 \mathrm{H}), 6.87(\mathrm{~d}, J=8.5$ $\mathrm{Hz}, 2 \mathrm{H}), 4.74$ (dd, $J=6.8,8.2 \mathrm{hz}, 2 \mathrm{H}), 4.42(\mathrm{~d}, J=2.3 \mathrm{~Hz}, 2 \mathrm{H}), 4.13$ (m, 2H), 3.83 (s, 3H), $3.76(\mathrm{~m}, 2 \mathrm{H}), 3.54(\mathrm{~m}, 3 \mathrm{H}), 3.43(\mathrm{~s}, 3 \mathrm{H}), 1.9(\mathrm{~m}, 6 \mathrm{H})$. 


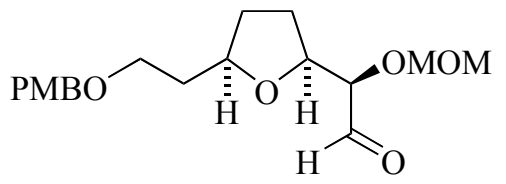

\section{Aldehyde 10}

To a solution of alcohol $9(456 \mathrm{mg}, 1.34 \mathrm{mmol})$ in $\mathrm{CH}_{2} \mathrm{Cl}_{2}(13 \mathrm{~mL})$ was added anhydrous $\mathrm{NaHCO}_{3}(1.12 \mathrm{~g}, 13.4 \mathrm{mmol})$, and Dess-Martin periodinane reagent $(830 \mathrm{mg}, 2.01 \mathrm{mmol})$ successively. After $1 \mathrm{~h}$ TLC analysis indicated the reaction was complete and saturated aqueous $\mathrm{NaHCO}_{3}$, and saturated aqueous $\mathrm{Na}_{2} \mathrm{~S}_{2} \mathrm{O}_{3}$ were added simultaneously and the mixture was extracted with ether. The ether extracts were separated, washed with brine, dried over $\mathrm{MgSO}_{4}$, filtered, and concentrated under reduced pressure to give an oil that was chromatographed on deactivated silica gel with 10:1 hexanes/Et ${ }_{2} \mathrm{O}$ as eluant to afford aldehyde $10(349 \mathrm{mg}, 77 \%) ;[\alpha]^{20}{ }_{\mathrm{D}}+4.4(c$ 1.00, $\left.\mathrm{CHCl}_{3}\right):{ }^{1} \mathrm{H} \mathrm{NMR}\left(300 \mathrm{MHz}, \mathrm{CDCl}_{3}\right)_{-} 9.70(\mathrm{~d}, J=1.7 \mathrm{~Hz}, 1 \mathrm{H}), 7.24(\mathrm{~d}, J=8.5$ $\mathrm{Hz}, 2 \mathrm{H}), 6.87(\mathrm{~d}, J=8.5 \mathrm{~Hz}, 2 \mathrm{H}), 4.75(\mathrm{~d}, J=2.1 \mathrm{~Hz}, 2 \mathrm{H}), 4.43(\mathrm{~d}, J=2.3 \mathrm{~Hz}, 2 \mathrm{H}), 4.25$ (m, 1H) $3.96(\mathrm{~m}, 2 \mathrm{H}) 3.80(\mathrm{~s}, 3 \mathrm{H}), 3.55(\mathrm{t}, J=6.5 \mathrm{~Hz}, 2 \mathrm{H}), 3.41(\mathrm{~s}, 3 \mathrm{H}), 2.04(\mathrm{~m}, 6 \mathrm{H})$.

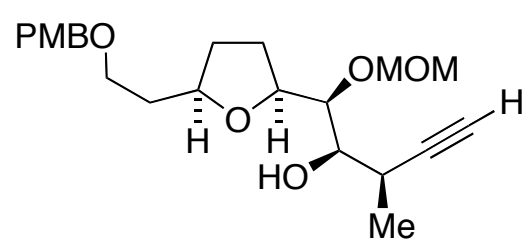

\section{Tetrahydrofuran Alcohol 12b}

To a stirring solution of $\mathrm{InBr}_{3}(43.0 \mathrm{mg}, 0.124 \mathrm{mmol})$ in EtOAc $(1.2 \mathrm{~mL})$ at $-78{ }^{\circ} \mathrm{C}$ was added aldehyde $\mathbf{1 0}(40.0$ $\mathrm{mg}, 0.118 \mathrm{mmol})$ and the $(M)$-allenylstannane deived from mesylate $\mathbf{1 1 b}(68.0 \mathrm{mg}, 1.99$ mmol) and the mixture was warmed to $0{ }^{\circ} \mathrm{C}$. After stirring for $2 \mathrm{~h}$, the mixture was quenched with water and extracted with ether. The combined extracts were washed with brine, dried over $\mathrm{MgSO}_{4}$, filtered, concentrated under reduced pressure, and chromatographed on silica gel (elution with 5\% EtOAc/hexanes) to give $43.5 \mathrm{mg}$ (94\% including some tin byproduct) of alcohol $\mathbf{1 2 b}$ as a 95:5 mixture of homopropargylic 
alcohol adducts as a clear oil. $[\alpha]^{20}{ }_{\mathrm{D}}-25.8\left(\right.$ ( $\left.1.00, \mathrm{CHCl}_{3}\right):{ }^{1} \mathrm{H} \mathrm{NMR}\left(\mathrm{CDCl}_{3}, 300 \mathrm{MHz}\right)$; $\delta 7.24(\mathrm{~d}, J=8.7 \mathrm{~Hz}, 2 \mathrm{H}), 6.86(\mathrm{~d}, J=8.7 \mathrm{~Hz}, 2 \mathrm{H}), 4.83(\mathrm{~d}, J=6.6 \mathrm{~Hz}, 1 \mathrm{H}), 4.76(\mathrm{~d}, J=$ $6.6 \mathrm{~Hz}, 1 \mathrm{H}), 4.43(\mathrm{~s}, 3 \mathrm{H}), 4.13(\mathrm{~m}, 1 \mathrm{H}), 3.98(\mathrm{~m}, 1 \mathrm{H}), 3.81(\mathrm{~s}, 3 \mathrm{H}), 3.52(\mathrm{~m}, 3 \mathrm{H}), 3.43(\mathrm{~s}$, 3H), $2.81(\mathrm{~m}, 1 \mathrm{H}), 2.12(\mathrm{~d}, J=2.7 \mathrm{~Hz}, 1 \mathrm{H}), 1.97-1.55(\mathrm{~m}, 6 \mathrm{H}), 1.28(\mathrm{~d}, J=6.9 \mathrm{~Hz}$, $3 \mathrm{H}), 0.92(\mathrm{t}, J=7.2,7.2 \mathrm{~Hz}, 3 \mathrm{H})$.

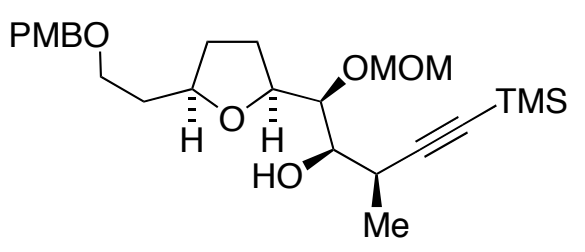

Tetrahydrofuran Alcohol 12c.

To a stirring solution of THF:HMPA $(3: 1,1.5 \mathrm{~mL})$ was added aldehyde $\mathbf{1 0}(100 \mathrm{mg}, 0.296 \mathrm{mmol})$

followed by $\mathrm{Pd}(\mathrm{OAc})_{2}(4.0 \mathrm{mg}, 0.018 \mathrm{mmol})$ and $\mathrm{PPh}_{3}(4.7 \mathrm{mg}, 0.018 \mathrm{mmol})$. Upon complete dissolution of the $\mathrm{PPh}_{3}$ the solution was cooled to $0{ }^{\circ} \mathrm{C}$. InI beads $(107 \mathrm{mg}$, $0.443 \mathrm{mg}$ ) were pulverized in a mortar and added to the solution followed by TMS mesylate $11 \mathrm{c}(91.0 \mathrm{mg}, 0.414 \mathrm{mmol})$. The solution was then stirred at $0{ }^{\circ} \mathrm{C}$ for $0.25 \mathrm{~h}$ before being warmed to rt. Upon completion of the reaction as judged by TLC analysis ( $0.5 \mathrm{~h})$ the reaction mixture was quenched with $10 \% \mathrm{HCl}$ and diluted with $\mathrm{Et}_{2} \mathrm{O}$. The organic layer was separated, dried over $\mathrm{MgSO}_{4}$, filtered, and concentrated under reduced pressure. The residue was chromatographed on silica gel (elution with $10 \%$ EtOAc/hexanes) to give $113 \mathrm{mg}(83 \%)$ of alcohol $\mathbf{1 2 c}$ as a light yellow oil. $[\alpha]^{20}{ }_{\mathrm{D}}-27.0$ (c 1.00, $\left.\mathrm{CHCl}_{3}\right):{ }^{1} \mathrm{H} \mathrm{NMR}\left(\mathrm{CDCl}_{3}, 500 \mathrm{MHz}\right) ; \delta 7.24(\mathrm{~d}, J=8.5 \mathrm{~Hz}, 2 \mathrm{H}), 6.87(\mathrm{~d}, J=8.5$ Hz, 2H), 4.89 (d, $J=10.0 \mathrm{~Hz}, 1 \mathrm{H}), 4.75(\mathrm{~d}, J=10.0 \mathrm{~Hz}, 1 \mathrm{H}), 4.43(\mathrm{~s}, 3 \mathrm{H}), 4.13(\mathrm{~m}, 1 \mathrm{H})$, $3.97(\mathrm{~m}, 1 \mathrm{H}), 3.81(\mathrm{~s}, 3 \mathrm{H}), 3.52(\mathrm{~m}, 4 \mathrm{H}), 3.42(\mathrm{~s}, 3 \mathrm{H}), 2.85(\mathrm{~m}, 1 \mathrm{H}), 1.97-1.65(\mathrm{~m}, 6 \mathrm{H})$, $1.25(\mathrm{~d}, J=7.9 \mathrm{~Hz}, 3 \mathrm{H}), 0.15(\mathrm{~m}, 9 \mathrm{H})$. 


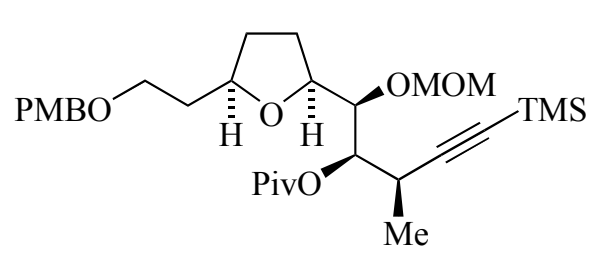

\section{Pivalic Ester 13}

To a stirred solution of alcohol $12 \mathrm{c}(0.150 \mathrm{~g}, 0.718$ mmol) in pyridine $(2 \mathrm{~mL})$ at $25^{\circ} \mathrm{C}$ was added pivalic

chloride $(0.114 \mathrm{~mL}, 0.933 \mathrm{mmol})$ and DMAP (cat.), with stirring at reflux. After $12 \mathrm{~h}$ TLC analysis indicated the reaction was complete and $\mathrm{H}_{2} \mathrm{O}$ was added and the mixture was extracted with ether. The combined ether extracts were washed $3 x$ with saturated aqueous $\mathrm{CuSO}_{4}$ then with water and brine successively and then dried over $\mathrm{MgSO}_{4}$. Concentration under reduced pressure gave pivalate $\mathbf{1 3}$ as an oil $(0.210 \mathrm{~g}, 100 \%)$. This oil was taken on without further purification: $[\alpha]^{20}{ }_{\mathrm{D}}-24.5\left(c 1.00, \mathrm{CHCl}_{3}\right):{ }^{1} \mathrm{H} \mathrm{NMR}(300$ $\left.\mathrm{MHz}, \mathrm{CDCl}_{3}\right)_{-} 7.24(\mathrm{~d}, J=8.5 \mathrm{~Hz}, 2 \mathrm{H}), 6.87(\mathrm{~d}, J=8.5 \mathrm{~Hz}, 2 \mathrm{H}), 5.00(\mathrm{t}, J=5.6 \mathrm{~Hz}$, 1H), 4.87-4.71 (dd, $J=6.7,13.0 \mathrm{~Hz}, 2 \mathrm{H}), 4.43(\mathrm{~s}, 2 \mathrm{H}), 3.97(\mathrm{~m}, 2 \mathrm{H}), 3.83(\mathrm{~s}, 3 \mathrm{H}), 3.68$ (m, 1H), $3.55(\mathrm{t}, J=1 \mathrm{~Hz}, 2 \mathrm{H}), 3.43(\mathrm{~s}, 3 \mathrm{H}), 3.05(\mathrm{~m}, 1 \mathrm{H}), 1.99(\mathrm{~m}, 2 \mathrm{H}), 1.86(\mathrm{~m}, 4 \mathrm{H})$, $1.26(\mathrm{~s}, 9 \mathrm{H}), 1.24(\mathrm{~d}, J=2.0 \mathrm{~Hz}, 3 \mathrm{H}), 0.16(\mathrm{~s}, 9 \mathrm{H})$.

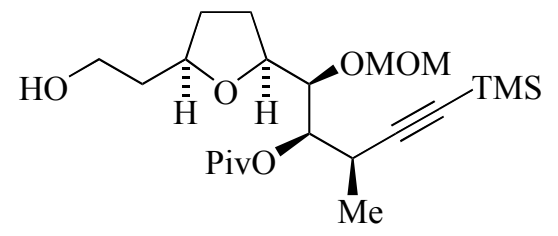
Alcohol 14
To a solution of crude pivalic ester $13(0.089 \mathrm{~g}, 0.162$ $\mathrm{mmol})$ in $\mathrm{CH}_{2} \mathrm{Cl}_{2}(1.62 \mathrm{~mL})$ and $\mathrm{pH} 7$ potassium phosphate monobasic-sodium hydroxide buffer $0.05 \mathrm{M}(0.09 \mathrm{~mL})$ was added DDQ $(0.055 \mathrm{~g}, 0.243 \mathrm{mmol})$ with stirring at rt. After $1.5 \mathrm{~h} \mathrm{TLC}$ analysis indicated the reaction was complete and saturated aqueous $\mathrm{NaHCO}_{3}$ was added and the mixture was extracted with ether. The combined ether extracts were washed with saturated aqueous $\mathrm{NaHCO}_{3}$ and brine successively and then dried over $\mathrm{MgSO}_{4}$. Concentration under reduced 
pressure followed by silica gel chromatography $\left(2: 1\right.$ hexanes/Et $\left.\mathrm{t}_{2} \mathrm{O}\right)$ gave alcohol $\mathbf{1 4}$ as a pale yellow oil $(0.070 \mathrm{~g}, 90 \%):[\alpha]^{20}{ }_{\mathrm{D}}-18.3\left(c 1.00, \mathrm{CHCl}_{3}\right):{ }^{1} \mathrm{H} \mathrm{NMR}(300 \mathrm{MHz}$, $\left.\mathrm{CDCl}_{3}\right)_{-} 5.03(\mathrm{t}, J=5.6 \mathrm{~Hz}, 1 \mathrm{H}), 4.86(\mathrm{dd}, J=6.7,13.0 \mathrm{~Hz}, 2 \mathrm{H}), 4.04(\mathrm{q}, J=2.6 \mathrm{~Hz}$, 2H), $3.82(\mathrm{~m}, 2 \mathrm{H}), 3.68(\mathrm{t}, J=5.9 \mathrm{~Hz}, 1 \mathrm{H}), 3.49(\mathrm{~s}, 3 \mathrm{H}), 3.0,(\mathrm{~m}, 1 \mathrm{H}), 2.03(\mathrm{~m}, 2 \mathrm{H}), 1.66$ (m, 4H), $1.33(\mathrm{~s}, 9 \mathrm{H}), 1.25(\mathrm{~d}, J=2.0 \mathrm{~Hz}, 3 \mathrm{H}), 0.29(\mathrm{~s}, 9 \mathrm{H})$.

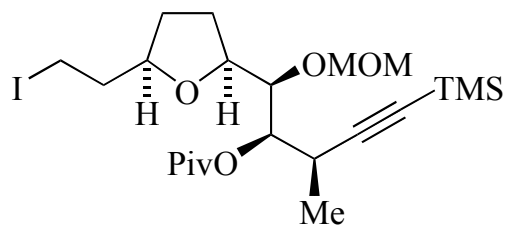

\section{Iodide 15}

To a solution of the above alcohol $14(60 \mathrm{mg}, 0.154$ mmol) in a 3:1 solution of ether:acetonitrile $(1.16 \mathrm{~mL}$ :

$0.385 \mathrm{~mL}$ ) at $0{ }^{\circ} \mathrm{C}$ was added imidazole (33 $\left.\mathrm{mg}, 0.485 \mathrm{mmol}\right), \mathrm{PPh}_{3}(69 \mathrm{mg}, 0.262 \mathrm{mmol})$, and iodine beads ( $66 \mathrm{mg}, 0.262 \mathrm{mmol}$ ) successively. The reaction was then allowed to warm to room temperature and was monitored by TLC until complete $\sim 1 \mathrm{~h}$. Saturated $\mathrm{Na}_{2} \mathrm{~S}_{2} \mathrm{O}_{3}$ was then added and the mixture was extracted with ether. The combined ether extracts were washed with brine, dried over $\mathrm{MgSO}_{4}$, filtered and concentrated to give an oil that was chromatographed on silica gel with 2:1 hexanes/ether as eluant to afford iodide 15 (57 mg, 70\%): $[\alpha]^{20}{ }_{\mathrm{D}}-32.6\left(c 1.00, \mathrm{CHCl}_{3}\right):{ }^{1} \mathrm{H} \mathrm{NMR}\left(300 \mathrm{MHz}, \mathrm{CDCl}_{3}\right)$ $5.04(\mathrm{t}, J=5.6 \mathrm{~Hz}, 1 \mathrm{H}), 4.81(\mathrm{dd}, J=6.7,13.0 \mathrm{~Hz}, 2 \mathrm{H}), 4.02(\mathrm{~m}, 1 \mathrm{H}), 3.94(\mathrm{~m}, 1 \mathrm{H}), 3.76$ (t, $J=5.6 \mathrm{~Hz}, 1 \mathrm{H}), 3.44(\mathrm{~s}, 3 \mathrm{H}), 3.33(\mathrm{~m}, 2 \mathrm{H}), 3.12(\mathrm{~m}, 1 \mathrm{H}), 2.08(\mathrm{~m}, 4 \mathrm{H}), 1.78(\mathrm{~m}, 1 \mathrm{H})$, $1.57(\mathrm{~m}, 1 \mathrm{H}), 1.3(\mathrm{~s}, 9 \mathrm{H}), 1.26(\mathrm{~d}, J=2.0 \mathrm{~Hz}, 3 \mathrm{H}), 0.23(\mathrm{~s}, 9 \mathrm{H})$.

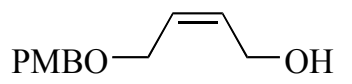

\section{4-( p-Methoxybenzyloxy)-2-buten-1-ol (17)}

To a mixture of $\mathrm{NaH}(60 \%$ wt., $1.07 \mathrm{~g}, 44.4 \mathrm{mmol})$ in THF $(90 \mathrm{~mL})$ at $0{ }^{\circ} \mathrm{C}$ was added (Z)-2-butene-1,4-diol (3.87 g, $44.4 \mathrm{mmol})$. After the mixture was stirred for $1 \mathrm{~h} \mathrm{PMBCl}$ 
(6.60 $\mathrm{g}, 44.4 \mathrm{mmol})$ was added, and the solution was stirred at rt. After $2 \mathrm{~h} \mathrm{TLC}$ analysis indicated the reaction was complete and aqueous $10 \% \mathrm{~K}_{2} \mathrm{CO}_{3}$ was added and the mixture was extracted with ether. The ether extracts were separated, dried over $\mathrm{MgSO}_{4}$, filtered, and concentrated to give $9.35 \mathrm{~g}$ of crude oil 17 which was taken on without purification. ${ }^{1} \mathrm{H}$ NMR $\left(300 \mathrm{MHz}, \mathrm{CDCl}_{3}\right)_{\text {_ }} 7.32(\mathrm{~d}, J=1.77 \mathrm{~Hz}, 2 \mathrm{H}), 6.93(\mathrm{~d}, J=1.70 \mathrm{~Hz}, 2 \mathrm{H}), 5.81$ (m, 2H), $4.49(\mathrm{~s}, 2 \mathrm{H}), 4.19(\mathrm{~d}, J=5.6 \mathrm{~Hz}, 2 \mathrm{H}), 4.03(\mathrm{~d}, J=5.9 \mathrm{~Hz}, 2 \mathrm{H}), 3.85(\mathrm{~s}, 3 \mathrm{H})$.

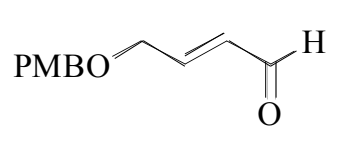

\section{4-(p-Methoxybenzyloxy)-2-butenal (18)}

To a solution of (Z) allylic alcohol $17(1.35 \mathrm{~g}, 6.46 \mathrm{mmol})$ in $\mathrm{CH}_{2} \mathrm{Cl}_{2}$ $(20 \mathrm{~mL})$ was added $4 \AA \mathrm{MS}(2.5 \mathrm{~g})$ and $\mathrm{PCC}(1.81 \mathrm{~g}, 8.40 \mathrm{mmol})$ at $0{ }^{\circ} \mathrm{C}$ and the mixture was stirred for 2 days at rt. After 3 days TLC analysis indicated the reaction was complete and the mixture was filtered through a pad of Celite and concentrated under reduced pressure to give a dark red oil 18 (2.34 g) that was taken on to the next step without purification. ${ }^{1} \mathrm{H}$ NMR $\left(300 \mathrm{MHz}, \mathrm{CDCl}_{3}\right) \_9.62(\mathrm{~d}, J=7.5 \mathrm{~Hz}, 1 \mathrm{H}), 7.32(\mathrm{~d}, J=$ $1.77 \mathrm{~Hz}, 2 \mathrm{H}), 6.93(\mathrm{~d}, J=1.70 \mathrm{~Hz}, 2 \mathrm{H}), 6.8(\mathrm{~m}, 1 \mathrm{H}), 6.44(\mathrm{dq}, J=2.0,5.9 \mathrm{~Hz}, 1 \mathrm{H}) 4.55$ (s, 2H), $4.28(\mathrm{~d}, J=2.0 \mathrm{~Hz}, 2 \mathrm{H}), 3.84(\mathrm{~s}, 3 \mathrm{H})$.

\section{$\mathrm{PMBO}^{\mathrm{OH}}$ 4-(p-Methoxybenzyloxy)-2-buten-1-ol (19)}

To a stirred solution of aldehyde $18(0.500 \mathrm{~g}, 2.39 \mathrm{mmol})$ in $\mathrm{CH}_{2} \mathrm{Cl}_{2}(23 \mathrm{~mL})$ at $-78^{\circ} \mathrm{C}$ was added DIBAL-H (1.0 M in hexanes, $3.60 \mathrm{~mL}, 3.60 \mathrm{mmol})$. The solution was stirred for $30 \mathrm{~min}$. then poured into a mixture of $50 \mathrm{~mL}$ of saturated Rochelle's salt solution and $50 \mathrm{~mL}$ of ether. Upon clarification, the organic layer was separated, dried over $\mathrm{MgSO}_{4}$, filtered and concentrated to yield an oil $19(0.734 \mathrm{~g})$ that was taken on without 
purification. ${ }^{1} \mathrm{H}$ NMR $\left(300 \mathrm{MHz}, \mathrm{CDCl}_{3}\right) \_7.32(\mathrm{~d}, J=1.77 \mathrm{~Hz}, 2 \mathrm{H}), 6.93(\mathrm{~d}, J=1.70$ Hz, 2H), $5.91(\mathrm{~m}, 2 \mathrm{H}), 4.49$ (s, 2H), 4.20 (d, $J=4.7 \mathrm{~Hz}, 2 \mathrm{H}), 4.05(\mathrm{~d}, J=4.6 \mathrm{~Hz}, 2 \mathrm{H})$, $3.84(\mathrm{~s}, 3 \mathrm{H})$.

$\mathrm{PMBO}$ OPiv (E)-4-(p-Methoxybenzyloxy)-2-butenyl Pivalate (20) To a stirred solution of allylic alcohol $19(0.150 \mathrm{~g}, 0.718 \mathrm{mmol})$ in pyridine $(2 \mathrm{~mL})$ at 25 ${ }^{\circ} \mathrm{C}$ was added pivalic anhydride $(0.114 \mathrm{~mL}, 0.933 \mathrm{mmol})$ and DMAP (cat.), with stirring. After $0.5 \mathrm{~h} \mathrm{TLC}$ analysis indicated the reaction was complete and $\mathrm{H}_{2} \mathrm{O}$ was added and the mixture was extracted with ether. The combined ether extracts were washed $3 \mathrm{x}$ with saturated aqueous $\mathrm{CuSO}_{4}$ then with water and brine successively and then dried over $\mathrm{MgSO}_{4}$. Concentration under reduced pressure gave pivalate 20 as an oil $(0.210 \mathrm{~g}$, $100 \%)$. This oil was taken on without further purification: ${ }^{1} \mathrm{H}$ NMR $\left(300 \mathrm{MHz}, \mathrm{CDCl}_{3}\right)$ $7.32(\mathrm{~d}, J=1.77 \mathrm{~Hz}, 2 \mathrm{H}), 6.93(\mathrm{~d}, J=1.70 \mathrm{~Hz}, 2 \mathrm{H}), 5.89(\mathrm{~m}, 2 \mathrm{H}), 4.61(\mathrm{~m}, 2 \mathrm{H}), 4.97(\mathrm{~d}$, $J=1.6 \mathrm{~Hz}, 2 \mathrm{H}), 4.04(\mathrm{~m}, 2 \mathrm{H}), 3.84(\mathrm{~d}, J=1.8 \mathrm{~Hz}, 3 \mathrm{H}), 1.25(\mathrm{~s}, 9 \mathrm{H})$.

\section{HO" OPMB (2R,3R)-1-Pivaloxy-4-(p-methoxybenzyloxy)-2,3-butanediol (21) HOPiv To a well stirred suspension of AD-mix- $\alpha(0.477 \mathrm{~g}, 1.4 \mathrm{~g} / \mathrm{mmol})$ in $t$ -} $\mathrm{BuOH} / \mathrm{H}_{2} \mathrm{O}(1: 1,3.5 \mathrm{~mL})$ was added methanesulfonamide $(0.032 \mathrm{~g}, 0.341 \mathrm{mmol})$ with stirring until both phases were nearly clear $(\sim 15 \mathrm{~min})$. The reaction mixture was cooled to $0{ }^{\circ} \mathrm{C}$ and olefin $20(0.100 \mathrm{~g}, 0.341 \mathrm{mmol})$ was added with a $t-\mathrm{BuOH} / \mathrm{H}_{2} \mathrm{O}$ rinse $(1 \mathrm{~mL})$. The mixture was allowed to warm to rt and stirred overnight. After $18 \mathrm{~h} \mathrm{TLC}$ analysis indicated the reaction was complete and saturated aqueous $\mathrm{Na}_{2} \mathrm{~S}_{2} \mathrm{O}_{3}$ was added and the mixture was stirred for $1 \mathrm{~h}$. The mixture was extracted with ether $(3 \mathrm{x})$ and the combined 
ether extracts were dried over $\mathrm{MgSO}_{4}$, filtered, and concentrated under reduced pressure. The residue was chromatographed on silica gel 2:1 Et ${ }_{2} \mathrm{O} / \mathrm{hexanes}$ to give diol $21(0.066$ g, 60\%): $[\alpha]^{20}{ }_{\mathrm{D}}+3.3\left(c 1.00, \mathrm{CHCl}_{3}\right):{ }^{1} \mathrm{H} \mathrm{NMR}\left(300 \mathrm{MHz}, \mathrm{CDCl}_{3}\right) \_7.30(\mathrm{~d}, J=7.7 \mathrm{~Hz}$, 2H), $6.93(\mathrm{~d}, J=7.0 \mathrm{~Hz}, 2 \mathrm{H}), 4.52(\mathrm{~s}, 2 \mathrm{H}), 4.20(\mathrm{~d}, J=4.84 \mathrm{~Hz}, 2 \mathrm{H}), 3.90(\mathrm{~m}, 1 \mathrm{H}), 3.84$ (s, 3H), $3.80(\mathrm{~m}, 1 \mathrm{H}), 3.63(\mathrm{~m}, 2 \mathrm{H}), 1.24(\mathrm{~s}, 9 \mathrm{H})$.

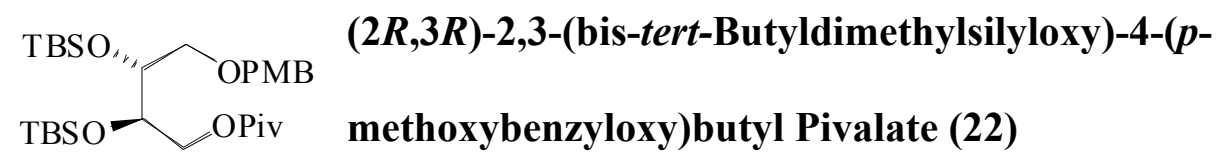

To a solution of crude diol $21(0.053 \mathrm{~g}, 0.162 \mathrm{mmol})$ in $\mathrm{CH}_{2} \mathrm{Cl}_{2}(1.0 \mathrm{~mL})$ were added triethylamine $(0.225 \mathrm{~mL}, 1.62 \mathrm{mmol})$ and $t$-butyldimethylsilyl trifluoromethanesulfonate $(0.171 \mathrm{~g}, 0.648 \mathrm{mmol})$, and the mixture was stirred at $0{ }^{\circ} \mathrm{C}$. After $0.5 \mathrm{~h}$ TLC analysis indicated the reaction was complete and ether and water were added. The ether extracts were separated and washed with saturated aqueous $\mathrm{NaHCO}_{3}$ and brine successively and then dried over $\mathrm{MgSO}_{4}$. Concentration under reduced pressure gave the bis-silyl ether $\mathbf{2 2}$ as an oil $(0.150 \mathrm{~g})$. This oil was taken on without purification to give fully protected $\mathbf{2 2}$ in $100 \%$ yield. $[\alpha]^{20}{ }_{\mathrm{D}}+25.1\left(\mathrm{c} 1.00, \mathrm{CHCl}_{3}\right){ }^{1} \mathrm{H} \mathrm{NMR}\left(300 \mathrm{MHz}, \mathrm{CDCl}_{3}\right)-7.32(\mathrm{~d}, J=$ $1.77 \mathrm{~Hz}, 2 \mathrm{H}), 6.93(\mathrm{~d}, J=1.70 \mathrm{~Hz}, 2 \mathrm{H}), 4.48(\mathrm{~s}, 2 \mathrm{H}), 4.27$ (dd, $J=3.6,2.6 \mathrm{~Hz}, 1 \mathrm{H}), 4.01$ (dd, $J=5.7,5.5 \mathrm{~Hz}, 1 \mathrm{H}), 3.97(\mathrm{~m}, 2 \mathrm{H}), 3.84(\mathrm{~s}, 3 \mathrm{H}), 3.67(\mathrm{dd}, J=1.1,7.7 \mathrm{~Hz}, 1 \mathrm{H}), 3.40$ (dd, $J=6.8,2.8,1 \mathrm{H}), 1.23(\mathrm{~s}, 9 \mathrm{H}), 0.90(\mathrm{~s}, 18 \mathrm{H}), 0.12(\mathrm{~s}, 12 \mathrm{H})$. 


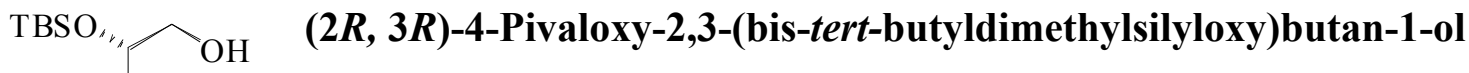 (23)}

To a solution of crude bis-protected silyl ether $22(0.089 \mathrm{~g}, 0.162 \mathrm{mmol})$ in $\mathrm{CH}_{2} \mathrm{Cl}_{2}(1.62$ $\mathrm{mL})$ and $\mathrm{pH} 7$ potassium phosphate monobasic-sodium hydroxide buffer $0.05 \mathrm{M}(0.09$ $\mathrm{mL})$ was added DDQ $(0.055 \mathrm{~g}, 0.243 \mathrm{mmol})$ with stirring at rt. After $1.5 \mathrm{~h}$ TLC analysis indicated the reaction was complete and saturated aqueous $\mathrm{NaHCO}_{3}$ was added and the mixture was extracted with ether. The combined ether extracts were washed with saturated aqueous $\mathrm{NaHCO}_{3}$ and brine successively and then dried over $\mathrm{MgSO}_{4}$. Concentration under reduced pressure followed by silica gel chromatography $(2: 1$ hexanes $\left./ \mathrm{Et}_{2} \mathrm{O}\right)$ gave alcohol as a pale yellow oil $(0.070 \mathrm{~g}, 99 \%$ over two steps) which was contaminated with inseparable $p$-methoxybenzaldehyde side products: ${ }^{1} \mathrm{H}$ NMR $(300$ $\left.\mathrm{MHz}, \mathrm{CDCl}_{3}\right)_{-} 4.35(\mathrm{dd}, J=2.8 \mathrm{~Hz}, 1 \mathrm{H}), 4.03(\mathrm{~m}, 1 \mathrm{H}), 3.89(\mathrm{~m}, 1 \mathrm{H}), 3.75(\mathrm{~m}, 2 \mathrm{H}), 3.61$ (m, 1H), $1.20(\mathrm{~s}, 9 \mathrm{H}), 0.91(\mathrm{~s}, 18 \mathrm{H}), 0.10(\mathrm{~s}, 12 \mathrm{H})$.

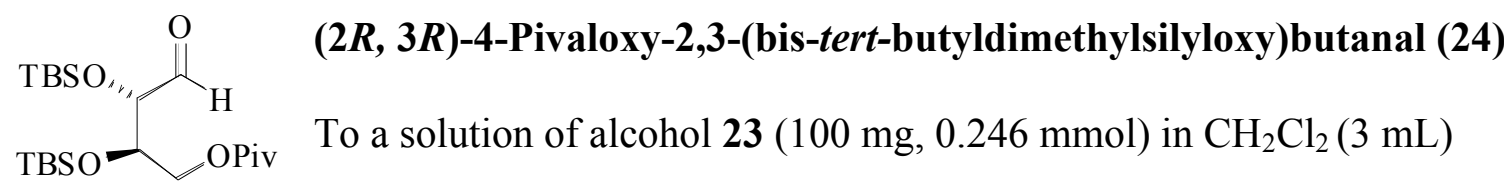
was added anhydrous $\mathrm{NaHCO}_{3}(203 \mathrm{mg}, 2.41 \mathrm{mmol})$, and Dess-Martin periodinane reagent (203 $\mathrm{mg}, 0.492 \mathrm{mmol}$ ) successively. After $1 \mathrm{~h} \mathrm{TLC}$ analysis indicated the reaction was complete and saturated aqueous $\mathrm{NaHCO}_{3}$, and saturated aqueous $\mathrm{Na}_{2} \mathrm{~S}_{2} \mathrm{O}_{3}$ were added simultaneously and the mixture was extracted with ether. The ether extracts were separated, washed with brine, dried over $\mathrm{MgSO}_{4}$, filtered, and concentrated under reduced pressure to give an oil that was chromatographed on deactivated silica gel with 10:1 hexanes/Et $2 \mathrm{O}$ as eluant to afford aldehyde $24[\alpha]^{20}{ }_{\mathrm{D}}+31.2\left(c 1.00, \mathrm{CHCl}_{3}\right):{ }^{1} \mathrm{H}$ 
NMR (300 MHz, $\left.\mathrm{CDCl}_{3}\right)_{-} 9.74(\mathrm{~s}, 1 \mathrm{H}), 4.20(\mathrm{~m}, 1 \mathrm{H}), 4.05(\mathrm{~m}, 3 \mathrm{H}), 1.17(\mathrm{~s}, 9 \mathrm{H}), 0.91$ (s, 9H), $0.87(\mathrm{~s}, 9 \mathrm{H}), 0.09$ (s, 12H).

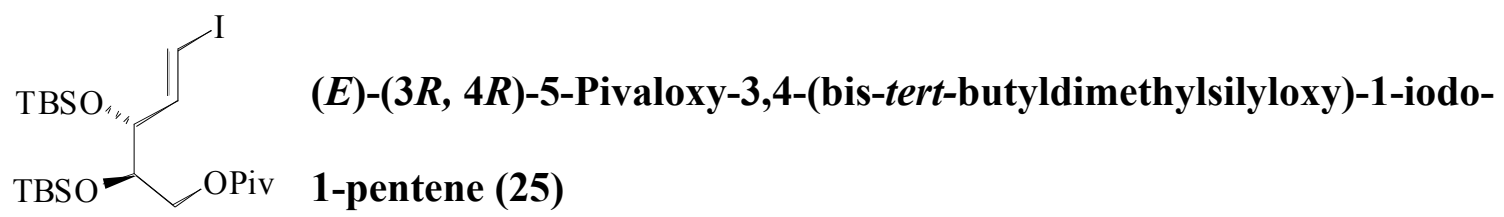

To a solution of $\mathrm{CrCl}_{3}{ }^{\bullet}(\mathrm{THF})_{3}(0.030 \mathrm{~g}, 0.074 \mathrm{mmol})$, zinc dust $(0.144 \mathrm{~g}, 2.21 \mathrm{mmol})$, and thoroughly dried $\mathrm{NaI}(0.055 \mathrm{~g}, 0.368 \mathrm{mmol})$ in dioxane $(3.68 \mathrm{~mL})$ was added freshly distilled TMSCl $(0.281 \mathrm{~mL}, 2.21 \mathrm{mmol})$ at $25^{\circ} \mathrm{C}$. After the mixture was stirred at $25^{\circ} \mathrm{C}$ for $40 \mathrm{~min}$. , a solution of aldehyde $25(0.161 \mathrm{~g}, 0.368 \mathrm{mmol})$ and iodoform $(0.289 \mathrm{~g}$, $0.736 \mathrm{mmol})$ in dioxane $(3.68 \mathrm{~mL})$ was added at $25^{\circ} \mathrm{C}$ over a period of $4 \mathrm{~h}$. After $8 \mathrm{~h}$ TLC analysis indicated the reaction was complete and the reaction mixture was poured into water and extracted with hexane. The hexane extracts were washed with saturated aqueous $\mathrm{Na}_{2} \mathrm{~S}_{2} \mathrm{O}_{3}$ and brine, dried over anhydrous $\mathrm{MgSO}_{4}$ and concentrated under reduced pressure. Purification by column chromatography on deactivated silica gel (hexane) gave vinyl iodide $25(0.155 \mathrm{~g}, 73 \%)$ as a colorless oil: $[\alpha]^{20}{ }_{\mathrm{D}}+15.8(c 1.00$, $\left.\mathrm{CHCl}_{3}\right):{ }^{1} \mathrm{H}$ NMR $\left(300 \mathrm{MHz}, \mathrm{CDCl}_{3}\right)_{-} 6.72(\mathrm{dd}, J=4.35,10.0 \mathrm{~Hz}, 1 \mathrm{H}), 6.33(\mathrm{dd}, J=$ 1.7, $12.7 \mathrm{~Hz}, 1 \mathrm{H}), 4.23(\mathrm{dd}, J=1.9,8.6 \mathrm{~Hz}, 1 \mathrm{H}), 4.24(\mathrm{~m}, 1 \mathrm{H}), 3.9(\mathrm{~m}, 2 \mathrm{H}), 1.17(\mathrm{~s}, 9 \mathrm{H})$, $0.91(\mathrm{~s}, 9 \mathrm{H}), 0.87(\mathrm{~s}, 9 \mathrm{H}), 0.09(\mathrm{~s}, 12 \mathrm{H})$. 


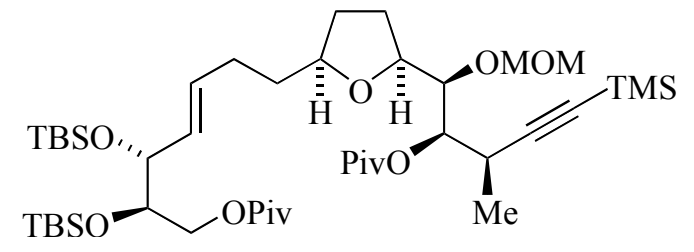

\section{Tetrahydrofuran 27}

To a solution of alkyl iodide $25(0.057 \mathrm{~g}, 0.106$ mmol $)$ in $\mathrm{Et}_{2} \mathrm{O}(1.43 \mathrm{~mL})$ at $-78^{\circ} \mathrm{C}$ was added

MeO-9-BBN (1.0 M solution in THF, $0.249 \mathrm{~mL}, 0.249 \mathrm{mmol})$ and $t$-BuLi $(0.189 \mathrm{~mL}$, $0.284 \mathrm{mmol}$ ) successively with stirring for $5 \mathrm{~min}$. After $5 \mathrm{~min}$ THF (1.42 $\mathrm{mL})$ was added and the mixture was warmed to $25^{\circ} \mathrm{C}$ with stirring for an additional $1 \mathrm{~h}$. After $1 \mathrm{~h}$ $\mathrm{K}_{3} \mathrm{PO}_{4}(3 \mathrm{M}$ solution $0.230 \mathrm{~mL}, 0.70 \mathrm{mmol})$, vinyl iodide $25(0.041 \mathrm{~g}, 0.071 \mathrm{mmol})$, and $\mathrm{Pd}(\mathrm{dppf}) \mathrm{Cl}_{2}(0.005 \mathrm{~g}, 0.007 \mathrm{mmol})$ were added successively with stirring. After $10 \mathrm{~h}$ TLC analysis indicated the reaction was complete and water was added and the mixture was extracted with ether. The combined ether extracts were washed with brine, dried over $\mathrm{MgSO}_{4}$, filtered and concentrated to give an oil that was chromatographed on deactivated silica gel with 1:1 hexanes/Et ${ }_{2} \mathrm{O}$ as eluant to afford Suzuki adduct $27(0.050$ $\mathrm{g}, 82 \%):[\alpha]^{20}{ }_{\mathrm{D}}-18.6\left(c 1.00, \mathrm{CHCl}_{3}\right):{ }^{1} \mathrm{H} \mathrm{NMR}\left(300 \mathrm{MHz}, \mathrm{CDCl}_{3}\right){ }_{-} 5.62(\mathrm{~m}, 2 \mathrm{H}), 5.00$ $(\mathrm{m}, 1 \mathrm{H}), 4.91(\mathrm{~d}, J=6.7 \mathrm{~Hz}, 1 \mathrm{H}), 4.76(\mathrm{~d}, J=6.2 \mathrm{~Hz}, 1 \mathrm{H}), 4.25(\mathrm{~m}, 1 \mathrm{H}), 4.14(\mathrm{~m}, 1 \mathrm{H})$, $4.00(\mathrm{~m}, 1 \mathrm{H}), 3.77(\mathrm{~m}, 1 \mathrm{H}), 3.44(\mathrm{~s}, 3 \mathrm{H}), 3.07(\mathrm{~m}, 1 \mathrm{H})$, ), $2.20(\mathrm{~m}, 2 \mathrm{H}), 1.85(\mathrm{~m}, 2 \mathrm{H})$, $1.80(\mathrm{~m}, 2 \mathrm{H}), 1.62(\mathrm{~m}, 2 \mathrm{H}), 1.27(\mathrm{~d}, J=1.9 \mathrm{~Hz}, 6 \mathrm{H}), 0.98(\mathrm{~d}, J=8.8 \mathrm{~Hz}, 18 \mathrm{H}), 0.25(\mathrm{~s}$, $6 \mathrm{H}), 0.18(\mathrm{~s}, 6 \mathrm{H}), 0.08(\mathrm{dt}, J=1.5,5.9 \mathrm{~Hz}, 9 \mathrm{H})$. 